\title{
Looking Back and Looking Forward: Adult Learnings from the Chinese Social Movement
}

\author{
Yong Fang Jia
}

\begin{abstract}
Drawing on theories in social movement, this paper provides a profile of the 1989 Beijing Student Movement (BSW): its recruitment, participation, leadership structures, and its basic cultural, symbolic, material resources as well as core repertoires. It is hoped to shed light on relevant studies of social movement learning in Chinese political environment.
\end{abstract}

Index Terms-Adult learning, social movement, tilly approach, knowledge production.

\section{INTRODUCTION}

It has been 24 years since 1989 student movement (SM) broke out in Beijing, China. Until now topic of this movement has been quite politically sensitive among Chinese people. The related literature review and theoretical exploration on 1989 BSM make me understand more of the movement. By connecting social movement (SM) theories with adult learning theories, I develop a new conceptual angle in my perception of the 1989 BSM. Particularly after reading Zhao's book (2001) and his other articles on 1989 BSM, I begin to try to frame my way of 'strategic adult learning' of 1989 BSM. [1]

In this paper I raise the research question: What conceptual overlaps between 'social movement theory' and 'adult learning theory' can be identified and explored from the 1989 BSM? This question is significant in that a lot of social problems occur in contemporary China, like loss of morality, lack of understanding of and concern toward democracy movement among younger generations. The question is answered through an exploration of the most pertinent factors in social movement learning, including political, economic, cultural factors with "Chinese characteristics". This article will firstly draws on the theories in social movement to provide a profile of the 1989 BSM: its recruitment, participation, leadership structures, and its basic cultural, symbolic, material resources as well as core repertoires. By exploring "Political Process Theories", Tilly approach, and collective learning theories, I put forward my argument that the oppressive political atmosphere and environment made the effective political reform-oriented social movement close to impossible while the 'strategic adult learning' could be adopted in the exploration of 1989 BSM. Then the paper identifies 'learning' from dimensions of social, cognitive and emotional, individual and collective, organized and informal. Finally the article draws implications and suggests further research by looking forward to the future of China and confirming the prospect

Manuscript received July 8, 2013; revised August 13, 2013.

Yong Fang Jia is with the OISE Student Success Center, University of Toronto, Canada (e-mail: jiayf98@gmail.com) faced by Chinese government for the enhancement of political reforms together with economic development, which, I sincerely hope and believe, could shed light on relevant studies of social movement learning in Chinese political environment.

\section{1989 BSM PROFILE}

Tilly (2004) regards that particular version of contentious politics requires historical understanding. [2] History helps because it explains why social movements incorporated some crucial features that separated the social movement from other sorts of politics and because it calls attention to the shifting political conditions that made social movements possible. This section summarizes the character of 1989 BSM by introducing its time, location, historical origins, recruitment and participation, basic cultural, symbolic and material resources, etc. for a better understanding of its outburst and development.

\section{A. Historical Origins}

In the spring of 1989 the world witnessed the well-known Student Movement in China's capital city of Beijing. The movement, also called Tiananmen Square Protests of 1989, was a series of demonstrations led by students, intellectuals, and labour activists in China between 15 April 1989 and 4 June 1989.

Internal and external factors influenced the student movement. Internally, during the 1980 s, as China carried out economic reform and open-door policy, Chinese economy developed quickly, while at the same time it confronted problems of inflation, widespread corruption, official profiteering, widening income gap and an increasing loss of faith in the leadership of Communist Party of China (CPC). Externally, the former Soviet Union President Mikhail Gorbachev's 'glasnost' and 'perestroika' were changing the face of communism. In addition, many anniversaries of historical importance, namely, the fortieth anniversary of the founding of the People's Republic of China, the seventieth anniversary of the $4^{\text {th }}$ May movement and the bicentennial anniversary of the French Revolution, influenced the students greatly. [3]

In the $1980 \mathrm{~s}$ Chinese students organized several demonstrations to express their dissatisfactions with the rule of CPC regime. In late 1985 and 1986, students in Beijing and Shanghai carried banners with slogans such as 'Law, Not Authoritarianism' and 'Long Live Democracy' in their protests. The 1989 Student Democracy Movement is the most significant outburst of students' protest.

\section{B. Recruitment, Participation and Leadership Structures}

Social movement is a trumpet call, a counterweight to 
oppressive power, and a summons to popular action against a wide range of scourges. Building a strong pro-democracy social movement is always the task of civil society when operating under an oppressive political environment. In 1989 BSM Students adopted different democratic forms of expressions in their recruitment, like demonstrations, wall posters, public gatherings and meetings. They incorporated various grievances on different campuses of colleges and universities. For a greater impact and to attract world attention, they erected the statue of the 'Goddess of Freedom' at the Tiananmen Square.

To attract the support of all sections of the society, the student leaders organized a hunger strike at the Tiananmen Square by making a highly-emotional statement which deeply attracted Chinese citizens who came out in large numbers to side with the students, especially Beijing residents. [4] Also, students' protests, demanding democratic reforms, were joined by urban working class, which began to advance far more radical social demands. According to the government's own figures, demonstrations occurred in each of China's twenty-nine provinces and in eighty-four of its cities. Over two million students from over six hundred institutions of higher learning nationwide participated. In Beijing alone, students from over eighty different colleges and universities converged on the capital to participate in demonstrations there. [5]

Students set up the autonomous student union of Beijing universities and colleges on 23 April 1989. It was broad-based and members were democratically selected by the representatives from forty-one universities. To meet the diverse needs of the movement, the students also set up new organizations, like, the Beijing Universities Students Group for Dialogue, comprising older, more experienced graduate students to facilitate a compromise/dialogue between the students and the government.

\section{Basic Cultural, Symbolic and Material Resources}

Students got support from local people, workers, foreign media, etc. The period of reform in China in which the movement occurred provided a political opportunity that allowed wide coverage of students' activities. The student-run journalism bureau set up to report on movement activities also raised money and had accounting systems to keep track of incoming funds. Several of the universities had radio broadcasting and printing stations set up for the duration of the movement. Also importantly, there were informal Democracy Salons, democracy associations, and action committees that began emerging as early as the 1980s.

As Walder argues, with sharp increases in telephone lines to the outside world, radios, photocopy machines, and faxes, the ability to communicate and distribute information widely endowed the student leaders with powers that leaders of other movements did not possess. [6] At the same time, with the presence of the foreign media, students and workers could meet foreign press agents directly and draw 'world-wide media attention' to specific confrontations.

\section{SM THEORIES \& THE 1989 BSM}

Because of its scale, duration, tragic ending, and impact on current Chinese politics, the 1989 BSM attracts a great deal of scholarly attention. Guthrie argues that the case of China in 1989 illustrates the need for a multivariate approach that is able to account for organization structure, collective action frames, and cultural repertories, as well as institutional and political opportunities. [7]

Social science research on movements and protests has flourished in the last three decades, especially in sociology and in the USA, from a marginal and eruptive field of study to a main, stable concern for researchers. In particular, resource mobilization and political process approaches became well-established frames of reference for research on social movements. [8] Guthrie describes McAdam's political process model (1982) as 'a general theory of insurgency...it includes the factors of expanding political opportunities, shared cognitions, shifting control responses of other groups, and indigenous organizational strength' (1995, p. 423). According to Tarrow, political process theory is similar to resource mobilization in many regards, in which political opportunities are the important component of social structure for social movement development. [9] Political process theory argues that there are three vital components for movement formation: insurgent consciousness, organizational strength, and political opportunities, which could be understood to refer to the above-mentioned parts in the previous section of analysis of 1989 BSM profile: historical origin, recruitment and leadership structures, cultural and material resources.

In studying Chinese leaders' crisis management, Liu argues that the controversy over the definition of the 1989 BSM among the Chinese Communist Party leaders in the initial period and their different stands toward the demonstration provide the political opportunity for its further development. [10] Wright also adopts the perspective of the political environment, particularly the political opportunity structure to analyse the failure of 1989 BSM. [11] She notes the Catch-22 faced by protesters in the most oppressive and exclusive regimes. To have a chance of success, they would need to forge strong links across varied social groups, such as workers. Yet the attempted mobilization of such groups that the regime finds threatening will provoke a rapid crackdown.

In addition, Tilly approach can also be adopted to analyse the 1989 BSM. Tilly (2004) defines social movements as a major vehicle for ordinary people's participation in public politics. He argues that there are three major elements to a social movement: (1) Campaigns: a sustained, organized public effort making collective claims of target authorities; (2) Repertoire: employment of combinations from among the following forms of political action: creation of special-purpose associations and coalitions, public meetings, solemn processions, vigils, rallies, demonstrations, petition drives, statements to and in public media, and pamphleteering and (3) WUNC displays: participants' concerted public representation of worthiness, unity, numbers and commitments on the part of themselves and/or their constituencies. This paper's previous section on analyses of 1989 BSM's historic origins, participation, recruitment and leadership structures, and culture, symbolic and material resources accord with the three social movement elements in Tilly approach, while Tilly approach provides people with a better historical understanding of the 


\section{BSM.}

Furthermore, the occurrence of 1989 BSM fits in with what Kilgore describes about the collective social action, which is motivated by norms of social justice, a collective sense of righting a wrong. [12] The collective challenge can take place in the form of a single incident like a sit-in, or in terms of a social movement in which a variety of means are used over time to challenge existing conditions or alternative social movement organization. The occurrence, development of 1989 BSM fell within the above description, and its recruitment went along as Mezirow (1989, quoted by Kilgore, 1999) describes that 'observations of recruiting efforts by social movement organizations reveal that the greatest source of new members is existing members' social networks, i.e. Friends are recruited by friends'. Zhao proves that in his analyses of rise and failure of 1989 BSM. He interviewed 70 students studying in China and Canada who participated in the movement and found that many students joined in the movement just because their classmates or friends did. At the same time, Mason \& Clements (2002) also adopt collective action theories to explain 1989 BSM. [13] They regard that rational choice models of dissident collective action focus on the binary choice between participating or not participating in activities that are proscribed by the state and therefore carry the risk of arrest, imprisonment, fines, injury, or even death. Since one's own contribution in and of itself is insignificant in determining whether or not collective action succeeds, a rational actor has an incentive to refrain from participating in and hopes that enough others will join the movement so that it does succeed. According to them, in authoritarian regimes, where dissident collective action is proscribed by the state and punished with sanctions of varying degree of harshness, potential participants consider the risks of participation. Thus, the likelihood that ordinary citizens will participate is conditioned by their estimate of the state's likely response to protest.

I agree with Mason and Clements. During the period of 1989 BSM, before June 4 repression, as more and more students joined in the demonstrations without being stopped and punished, other students felt secured in their own participation. Some even took chances to visit Beijing Tiananmen square where they hadn't been before. However, after June 4 repression, students began to realize the severe consequence for the participation, so they denied going to Beijing and joining in sit-ins, particularly denying participating in June 4 protest, whether in Beijing or their hometowns. People's estimate of the state's likely response to dissent influences their behaviours for future actions, which is why so far in current China the similar student movement has been absent and even people avoid talking about the topic of 1989 BSM.

\section{KNOWLedge Production ANd LEARNing}

Eyerman and Jamison (1991, cited by Holford, 2005), propose that social movements should be seen "not merely as a challenge to established power, but also and more so as a socially constructive force, as a fundamental determinant of human knowledge; social movement is 'cognitive praxis', from which science and ideology- as well as everyday knowledge- develop new perspective". [14]. This section identifies 'learning' from dimensions of social, cognitive and emotional, individual and collective, organized and informal, based on literature review of social movement learning and adult learning.

\section{A. Social, Cognitive and Emotional Dimensions of Learning}

Illeris (2002, cited by Sawchuk, 2007) holds that human learning always involves three dimensions at the same time: cognitive, emotional, and social, mapped onto what Illeris calls a 'tension field' of learning. Individual cognition is one of the most persistent, orienting principles of mainstream learning theory as well as conventional thought in both schools and workplaces alike. [15] Just as cognition matters, so too does emotional development shape adult learning. Social learning is deeply shaped by social interaction, composed of a system of domination and power that produces distortions of experience through systematic patterns of distribution of communicative resources.

The 1989 Student Democracy Movement ended in failure. Dan Wang, one of the student leaders of the movement, argues that failure of the movement has caused Chinese people to avoid political participation and thus lack of political reform and corruption still continue in Chinese society. [16] Therefore, the social learning, also cognitive one reflected from this movement can be that instead of pushing society forward in certain aspects, like democracy, political reform, etc., the failure of movement might lead to retrogress of society in the aforementioned aspects. Analysed from perspective of emotional dimension of learning, such retrogress is what participants feel most painful and unwilling to see.

There are several learnings drawn from the failure of the movement. From social dimension, with the economic reform and improvement of people's living standard, it's not easy to change people's attention from making money to political movement. From the cognitive dimension, the disintegration of the former Soviet Union teaches Chinese people a lesson to keep stable in the socio-political system. Sawchuk, draws on the concept of 'cultural hegemony', suggests that the model of how cultural domination is accomplished in modern societies is applicable to contemporary thinking about the concept of learning. [17] Specifically, it helps us to understand how both the dominated and the dominant play an active role in the construction of what means to learn in this day and age (p. 24). The historical bloc, in principle, that dominant articulating themes produce privileges certain practices while obscuring, denigrating, or denying others (Gramsci, 1997 cited by Sawchuk, 2003), is valuable in explaining the general direction of current social and cognitive learning in China.

Considered from emotional dimension, although individuals may be compelled to suppress feelings in the organizational context, yet different social contexts and practices make it possible for individuals to pursue emotional fulfilment and self-realization. In social movements, the process of emotional achievement among participants unfolds as a process of mobilization. An analysis of the emotional dynamics of the 1989 Chinese 
student movement shows that emotions were inextricably intertwined with identities and action and that the emotional dynamics generated in this process significantly contributed to movement mobilization. [18] In addition, Zhao regards that the 1989 Movement tended to be driven by emotions, rumours, and traditional cultural elements exactly because it developed under an authoritarian state with higher state unity and the capacity to penetrate society, a society with very weak development of intermediate organizations, and a state legitimation based on moral and economic performance. What the resurgence of traditionalism during the 1989 Movement teaches us is that cultural and emotional claims might gain new purchase, at least in the political sphere, under certain other structural transformations.

\section{B. Collective and Individual Dimensions of Learning}

Kilgore proposes that a theory of collective learning is more appropriate than individualized theories for the study of individuals and groups engaged in collective action to defend or promote a shared social vision. A theory of collective learning would examine the dynamic interaction and mutual development of individual meaning and shared meaning, while the collective learning process of developing a collective identity and the nature of that identity- shared goals, meaning, strategies- is more pertinent than an individual's learning. [19] Kilgore argues that we should turn our dominant focus in learning theory from individuals' inner understandings to an exploration of the learning community, because it is the dominant shared meaning and identity of the collective that is most closely related to collective social action. In the 1989 BSM, most students got in touch with the knowledge on anti-corruption, democracy, political reform from the collective social action. To them this collective learning was encouraging, stimulating, productive, and also in a collective sense, relatively riskless.

Individual learnings follow. Dr. Zhao, a sociologist in University of Chicago, has written and published a lot of books and articles on the 1989 BSM, while he has been invited by many Chinese universities to present on political sociology. I was very surprised and also excited to find a way of learning from and doing studies on the 1989 BSM. Tilly (Foreword, in Zhao, 2001) pointed out that Zhao has recognized his home, but as only an insider who has journeyed elsewhere, which means that due to the 1989 BSM Zhao changed his role from an entomologist to a sociologist, an expert analyst of the Tiananmen mobilization, while this change could only be done when he left China and pursued his Ph.D. program in Montreal, Canada. In writing the book on Tiananmen Square Zhao is characterized by his analyses as mechanism-based explanations in which activation of propensities plays a significant part, which is a strategy Zhao adopts to reduce the risks of his daring enterprise (Tilly, p. Xiii). Though Zhao also describes the 1989 BSM as Tiananmen massacre, yet his analyses of and comments on the rise and failure of student movement could provide Chinese government with information on how the regime should perform later in future to avoid the similar democracy movement from happening. This kind of 'strategic 1989 BSM learning' gives me much inspiration in the method I could use in my Tiananmen movement research. In the next section of 'Further Research' I will connect the study of 1989 BSM with Chinese rural migration movement: how the measures Chinese government took in economic reform after 1989 BSM influence rural people's lives, which leads to their mass migration, and how Chinese government should be on guard in case of the future social unrest resulting from social problems in the rural migration.

\section{Organized and Informal/Everyday Dimensions of Learning}

"The concept of learning as a developmental 'activity system' includes both organized and informal, everyday learning" (Sawchuk, 2007). According to Francis (1989), during the movement the students' demand for recognition of their autonomous organization was obviously a move forward, which made the principle of society's right to self-determination- its right to organize independently and to represent itself through autonomous associations- the key agenda of China's democratic movement.

As people live and work they continually learn. Most of this learning is unplanned, and it is often tacit; but it is very powerful. [20] People's accounts of 'informal learning' in particular are susceptible to the effects of power. Informal learning is recognized most readily when these practices are based in a social community that legitimizes them. Dominant class groups find this legitimacy all around them, but for subordinate groups it is more difficult to come by and must be actively created. [21] During the 1989 BSM, students obtained learning in hegemonic struggle, which refers to challenging, seeing through and bringing down the powerful (Foley, 2001). This learning is fundamental to emancipatory learning, about which Foley uses examples of a parson described by Cobbett and that of landlords in the Land Reform in China. This is informal and complex learning. Students organized protests and hunger strike during the national visit of the former Soviet Union President Mikhail Gorbachev, and later requested the televised dialogue with Premier $\mathrm{Li}$, which, in eyes of authoritarian Chinese Communist Party, is unbearable humiliation and thus partially leads to the future ruthless repression. Analysed from the negative aspect, this informal learning of hegemonic struggle needs to be adopted prudently in Chinese political circumstances.

On the other hand, despite the failure of the 1989 BSM, the informal learning could be achieved by combining with the movement participants' 'meaningful learning' and facilitation (Foley, 2001), which refers to that the self-initiated learning is involved in the whole person and the focus of work in learning groups is 'the honest artistry of interpersonal relations' (p. 73). Reflections from 1989 BSM participants on the failure are meaningful and important learning which increases people's awareness of themselves and others, and also changes their behaviours and attitudes toward life and society.

\section{CONCLUSION, IMPLICATIONS AND FURTHER RESEARCH}

This paper examines and identifies conceptual overlaps between 'social movement theory' and 'adult learning theory' from the 1989 BSM. By drawing on Political Process Theories, Tilly approach and theory of collective learning, it 
explores the most pertinent factors in this social movement learning, including political, economic and cultural factors with "Chinese characteristics". While arguing that the oppressive political atmosphere and environment made the effective political reform-oriented social movement close to impossible, the paper confirms the urgency for the enhancement of democratic politics in the development of China. The study is significant in understanding the increasing social problems in Chinese current situation and looking forward to the future of China to draw implications and provide insightful further research suggestions for related studies of social movement learning.

Implications of the 1989 BSM learning could be drawn from the literature review. The first is about individual learning or collective learning. Kilgore gives priority on collective learning in social movement to individual learning, and another kind of collective social action is rampant: network social comments and protest against social problems, which offers a 'framework of collective learning' in which we can examine how people construct shared visions of social justice and learn, act together to promote these shared visions (Kilgore, 2001). After a certain social problem is exposed on Internet, people express their feelings and call for actions to solve the problem. Many of these social actions behind the scene do work, arousing the public concern and contributing to the solution, though these social actions are based on individual consideration of safety. Therefore the network social movement, being a powerful mechanism for social justice in China, deserves more attention and insightful further studies from sociologists and social workers.

After 1989 BSM, Chinese leader Deng Xiaoping restated his commitment to capitalism, Chinese style, a new mode of concern with moneymaking which overtook all sectors of people. The active ranks of the prodemocracy movement became much thinner and demand for democracy and political reform fell, particularly among the city folk who had supported the student movement in 1989 and who were now busy trying to take advantage of the opportunities that Deng's new policy had opened up for them. [22] Also the government implemented a series of policy decisions that had the effect of transferring financial resources from the rural sector to the urban economy. The state lowered the price it paid for quota grain and ceased guaranteeing the price of above-quota grain (Mason \& Clements, 2002, p. 168). This policy benefits the urban population most by doubling their per capita income while per capital rural income rose slightly. Between 1992 and 1993, urban income per capita increased by another 12 percent, while rural income increased by only 2 percent. [23]

The income gap between rural and urban areas has grown accordingly, which stimulates the large internal migration from rural areas to urban areas in Chinese history. As Chinese economy develops, more and more social problems have resulted from the rural migration, including social security of migrant workers, education of their children, and vocational training for migrant workers, etc. While the first generation of migrant workers work hard mainly for the economic position in life, the second generation who have grown up in urban areas but have no identities and sense of belonging also call for political position as well in society.
They are the potential force of social unrest and social movement, which is an important area for further research to be conducted on. [24] Sawchuk (2007) claims that analysis of the mechanisms of human development can make an important contribution to a more coherent understanding of the on-going processes of reproduction and development of economic and labour relations. Political significance found in the mundane, hidden and taken-for-granted world of everyday lives of working people will shed lights on helping to solve social problems resultant from 1989 BSM, like rural migration, official corruption, etc., and contributing to the development of political reform, which has long been expected by all Chinese people.

\section{REFERENCES}

[1] D. Zhao, The Power of Tiananmen: State-society Relations and the 1989 Beijing Student Movement, Chicago, The University of Chicago Press, 2001.

[2] C. Tilly, "Social Movements as Politics," in Social Movements, C. Tilly, ED. Boulder: Paradigm Publishers, 2004, pp.1-15.

[3] D. Panda, "Student movement in Post-Liberation China," China Report, vol. 35, pp. 183-189, 1999.

[4] L. Pye, "Tiananmen and Chinese political culture," Asian Survey, vol. 4, pp. 342-343, April 1990.

[5] J. Tong, "The 1989 democracy movement in China: A spatial analysis of city participation," Asian Survey, vol. 3, 310, 1998.

[6] G. Walder, "The political sociology of the Beijing upheaval of 1989," Problems of Communism, vol. 38, pp. 30-40, 1989.

[7] D. Guthrie, "Political theatre and student organizations in the 1989 Chinese movement: A multivariate analysis of Tiananmen," Sociological Forum, vol. 3, pp. 419-54, 1995.

[8] D. McAdam, S. Tarrow, and C. Tilly, "Dynamics of contention. Social Movement Studies," vol. 1, pp. 97-98, 2003.

[9] S. Tarrow, Power in Movement, New York: Cambridge University Press, 1998.

[10] A. Liu, "Aspects of Beijing's crisis management: The Tiananmen Square demonstration," Asian Survey, vol. 5, pp. 505-21, 1990.

[11] T. Wright, The Perils of Protest: State Repression and Student Activism in China and Taiwan, University of Hawaii Press, 2001.

[12] D. Kilgore, "Understanding learning in social movements: A theory of collective learning," International Journal of Lifelong Education, vol. 3, pp. 191-202, 1999

[13] T. Mason and J. Clements, "Tiananmen Square thirteen years after: The prospects for civil unrest in China," Asian Affairs, vol. 3, pp.159-188, 2002.

[14] J. Holford, "Why social movements matter: Adult education theory, cognitive praxis, and the creation of knowledge," Adult Education Quarterly, vol. 2, pp. 95-111, 2005.

[15] P. Sawchuk, "Understanding diverse outcomes for working-class learning: Conceptualizing class consciousness as knowledge activity," The Economic and Labour Relations Review, vol. 2, pp. 199-216, 2007.

[16] D. Wang, "On the frontiers of free speech," China Rights Forum, vol 2, pp. 80-87, June 2009.

[17] P. Sawchuk, Adult Learning and Technology in Working-Class Life. New York: Ambridge University Press, 2003.

[18] G. Yang, "Achieving Emotions in Collective Action: Emotional Processes and Movement Mobilization in the 1989 Chinese Student Movement," Sociological Quarterly, vol. 4, pp. 593-614, 2000.

[19] D. Pillory, "Understanding learning in social movements: A theory of collective learning," International Journal of Lifelong Education, vol. 3, pp. 191-202, 1999.

[20] G. Foley, "Radical Adult Education and Learning," International Journal of Lifelong Education, vol. 20, pp. 71-88, 2001.

[21] D. W. Livingstone, D. Martin, and P. Sawchuk, "Starting with workers: Researching the hidden dimensions of the knowledge society the 'hard way," in Hidden Knowledge: Organized Labour in the Information Age, D. Livingstone and P.Sawchuk, Ed. Toronto and Boulder: CO. Garamond Press and Rowman \& Littlefield, 2004, pp. 251-281.

[22] J. Beja, "China since Tiananmen," Journal of Democracy, vol. 3, pp. 20-22, July 2009.

[23] L. Cheng, "Surplus rural labourers and internal migration in China: Current status and future prospects," Asian Survey, vol. 11, pp. 1129-1130, 1996. 
[24] J. Yu and P. Wei, "Different migrant workers possess different politics," China Studies, March 2010.

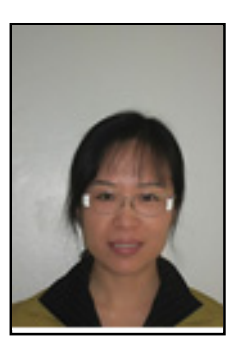

Yong Fang Jia was born in China. She is currently a doctoral candidate in Ontario Institute for Studies in Education (OISE), University of Toronto, Ontario, Canada. In 2006 she earned her master of arts degree in applied linguistics, Faculty of Arts, York University, Toronto, Canada, while in 2002 earning Master of Arts degree in linguistics, Xi'an Foreign Languages University, Shan'xi, China.

She is the Academic Advisor in OISE Student Success Center, University of Toronto, Canada, while also working as a Research Assistant and Coordinator for projects in her department. She is awarded Ontario Graduates Scholarship (OGS) for 2013-14 (also 2012-13) to work on her thesis research in area of workplace learning and social movement. She is associate professor in Inner Mongolia University of Technology, China. She published over 30 papers in overseas and domestic journals in fields of applied linguistics, social science and humanities.

Prof. Jia is the member of American Educational Research Association. 